\title{
A Conceptual Study Of Privatization Of Public Enterprises And Industrial Relations Practice In A Mixed Recessional Economy
}

D. I. Akintayo, Osun State University, Nigeria

\begin{abstract}
This paper examines the effect of privatization of public enterprises on industrial relations practice in a mixed recessional economy. This is with a view to ascertaining the economic effect of privatization on labour-management relations in Nigeria. The qualitative approach was adopted for this study. The paper submits that privatized public enterprises in a recessional economy does not create enabling environment for harmonious labour-management relations. Also, it is established that though privatization policy implementation enhances efficiency and improved workers' performance, however, retrenchment and job insecurity of the workers are always the resultant effects of any privatized public enterprises. Therefore, it is recommended that privatization policy implementation should be normally be designed to guarantee workers' job security, while pragmatic efforts towards sustaining the level of efficiency and productivity attained by the privatized public enterprises should always be given a priority.
\end{abstract}

Keywords: Conceptual study; Privatization; Public Enterprises; Industrial Relations; Recession, Mixed Economy

\section{INTRODUCTION}

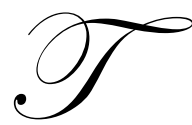

he economic effect of privatization on labour-management relations in a recessional has always been the bane of privatization of public enterprises (PEs) as it is always be the case in Nigeria. Perhaps, the strongest of the arguments for privatization is the fiscal crisis of the state and the implied need to reduce government expenditure by stopping the subsidy or subvention to the parastatals, and thus increasing government revenue by selling the PEs to private sector. Given this, it is thought that, budget deficits can be avoided and government would secure more funds for reviving the depressed economic. An associated argument to this is that, the annual losses, poor performance and non-competitive operation of the PEs can no longer be tolerated under the financial strains of the country. Thus, people readily cite persistent power failure from the National Grid, National Electric Power Authority (NEPA), water shortages from Water Corporation and the reported inability of various Public Enterprises to generate financial profit as evidence of their non-viability. Hence, they should be sold out and subjected to the alleged managerial efficiency and profit orientation of the profit sector - as if all private enterprises are profitable ventures (Onimode, 2000).

However, the ideological motive in privatization of public enterprises advanced that "government has no business in business". So, it is claimed that government has been interfering too much in economic activities rather than concentration on its function of governance. Thus, the privatization of PEs is therefore the answer as it is the case with the United States of America.

At the level of industrial relations politics, the proponent of unmitigated efficiency also insists that the PEs is inexcusably over-staffed. This is alleged to have saddled these parastatals with excessive labour cost and overhead expenses, hence, their inability to generate profits. The privatization of such enterprises is then said to be necessary in order to minimize their costs by reducing their staff (as if labour cost is the most important determinant of profit in an enterprise). Given this background, it will be argued in this paper that these arguments are mere 
excuses for harking PEs to a handful of greedy capitalists.

\section{MAIN FEATURES OF EMPLOYMENT RELATIONS IN A MIXED RECESSIONAL ECONOMY}

In order to analyze how the privatization of PEs affects industrial relations in a mixed recessional economy, it is necessary to first examine the main features of these relations. In the world of work, which requires interaction among the workplace; we can easily see how the actors in industrial relations (the Government and its agencies, the Employers and their associations and the Employees and their organizations) are influenced by the pressures of privatization. Also, these features of employment relations will be discussed with respect to the three main actors in industrial relations and with reference to the labour, employers (that is, private sector, both local and foreign) and government.

\section{LABOUR ORGANIZATIONS IN RECESSIONAL PERIOD}

In a recessional economy, employment relations according to Onimode (2001) affects labour, that is, the working class in six main ways. These are in the areas of restrictions, delayed payments, reduced service conditions and lower labour participation in decision-making process. Onimode contends further that these have all become fairly common in Nigeria since the recession started in the mid of 1981. The worst effect of recession on labour is massive unemployment and heavy retrenchment of workers in the name of the so called rationalization. Thus, the current depression has rendered some 3 million workers jobless since mid-1986, and the retrenchment is still continuing both in the private and public sectors. The problem has been compounded by the gross mismanagement of the economy under the military administration, between 1986 - 1995, and also by the multinational penchant for raising capital intensity by replacing workers with machines, as well as by the scarcity of imported raw materials and spare parts. The fiscal crisis of the state and International Monetary Fund (IMF) and World Bank insistence on deflationary policies and the organizational or political weakness of the Nigerian Labour Congress (NLC), which is the central labour organization is Nigeria, also contributed to the problem.

As the recession has been a veritable stagflation with rising unemployment, and pernicious inflation, workers real wages or real earning has been falling drastically. This is not just the usual phenomenon of wages lagging behind prices during inflation. Rather, it is fixed and constant money wages being viciously gobbled up by two or more digit inflation. The absence of any indexation of wages under fixed minimum remunerations is the problem. The Productivity, Prices and Incomes Board (P \& IB) with its in-built commitment to low wages is also central to this massive erosion of real earnings (Akintayo, 2004 and Ogunde, 2002). This is compounded by wage freeze and a total ban or stiff restrictions on strikes. So, money wages are pegged and as inflation eats them up, the trade unions are not allowed to go on strike to defend their industrial status and economic gains over the years. These withering labour disabilities are designed paradoxically to maintain industrial harmony. This is not to deny the fact that recessions are major periods for keeping the protests of labour in check. The point is that, this check on labour protest is not usually exercised so directly by employers` prerogative but through negotiation and collective agreement.

In addition to these developments, multiple levies and the withdrawal of fringe benefits are imposed. So, just as the real value of private wage is being eroded by inflation, the size of the social wage (welfare benefits like subsidized education, health care, petrol, etc.) is also being assailed. In the same vein, Ogunde (2002) argues that it is this double barrage of assault against labour rewards under austerity measures that make these policies so intimately repressive. As if these are not bad enough, labour earnings often fall into arrears for months as in the recent practice of federal government paid labour. And, as government functionaries are being favoured with their pay, others are denied theirs in the name of austerity. This is yet another clear case of the uneven distribution of wealth and the burden of adjustment to this economic crisis. All these do not deny the need for some hardship during the processes of planning recovery from the economic crisis. What is contended is that the distribution of the burden of adjustment is grossly loaded against labour.

For all these reasons, labour has been experiencing a reduction in the level of its participation in the economy. Besides the above factors, this relative loss of status by labour has resulted also from the increasing relative fortunes of other social groups. This fact, supports the view of Okegbenro (2002) who posits that, while 
money wages have been frozen and real labour earnings have been falling drastically, the profits of several enterprises have been doubling annually since 1983. This reduction in the level of labour participation is accordingly reflected in the reduced share of labour income in total earnings as well as the reduction of the labourcapital ratios and the increased marginalization of labour in management and decision-making process, due to the pressures of rationalization. In essence, privatization of public industries has fostered workers`alienation which has made labour worked more at reduced share of income in total earnings. Thus, the marginalization of workers in the interest of rationalization had undermined the principles of industrial democracy, which tends to attenuate managerial efficiency and profitization of the privatized industries.

\section{THE ROLE OF PRIVATE EMPLOYERS}

The manifestations of employment relations in mixed recessional economy with respect to the privatesector employers are threefold. These are the greater concentration of power over ownership, control and earnings in the hands of management. This is the converse of the reduced participation of labour in decision-making and earnings. As employment relations are basically a two-person affair (employers and labour organizations), which involves zero-sum game - that is, what the workers lose in the relationship, is often being gained by the employers in terms power structure and wealth distribution. In the interest of rationalization and austerity, therefore, the employers often concentrated the decision-making power in their own hands and diminished consultations with workers, who instead were being retrenched, and employers virtually relied more on consultation with outside 'experts' for advice (Obadan, 2003). Given this, the limited participation of labour in management during the recession has drastically portrayed the employers as becoming more authoritarian and bellicose under the excuse of the deteriorating business environment. Labour is thus singled out as the villain of the piece, even by the most incompetent management because of the general atmosphere of insecurity of job. Workers tend to accept this meekly because of its drastically reduced moral integrity under the dangling decision on retrenchment of striking workers in the workplace. Democracy is thus abandoned and employers attained the apex of their domination of labour-management relations as workers' rights are openly abused and industrial democracy is thrown to the wind (Olashore, 2000, Zubairu, 2003, and Adeola, 2003).

However, privatized public enterprises seem to be the ideal setting for the greater exploitation of labour under the combined slogans of rationalization and austerity measures. Zubairu (2003) reported that as a general atmosphere of siege and authoritarianism fill the air, all sorts of measures to curtail workers' rights and privileges are introduced. Just as labour is losing ground in these ways, the employers are drumming a frenetic campaign about the need for higher productivity from workers in order to achieve economic recovery. The point here is not that increased productivity is not desirable, but it cannot be achieved, and it should not be greater recession and marginalization of labour. If workers must produce more, they must be well motivated at workplace. So, a situation in which rationalization and repressive industrial measures have been doubling profits annually but stagnating wages is unjust and untenable. Yet, this is what obtain, and as recession increases, the exploitation of workers in several ways (that is, through fixed wages and rising profits, reduced fringe benefits, higher capital - labour ratio, and job insecurity), it generates higher super-profits, especially to the multinationals, from cowed and docile labour force. This is one of the abnormal aspects of the Nigerian recessional economy. Whereas a recession typically reduces all incomes, including profits, the current one in Nigeria has been doubling profits annually for many enterprises (Omole, 2003).

This situation has led to the second queer aspect of the recession in Nigeria. This implies that, recession in Nigeria has led to financial crisis for government and to a financial boom for the capitalists. So, governments (local, state and federal government agencies) now have to launch appeal funds to reach individuals for funding vital state activities. Onimode (2000) asserts that perverse redistribution of resources from the governments and poor masses to the capitalists has been so great that the private sector now feels strong enough to bid for the take-over of vital public enterprises. This is what has materialized as the current clamour and jittery exercise of the privatization of public enterprises. Lest the apostles of greater capitalism should see this as vindicating their positions, we must insist that the massive redistribution of resources to capitalists has been basically the consequence of years of pirate capitalism (that is, the frocracy). This is the system in which the illegitimate and even illegal plundering of the state has been the main source of the private accumulation of wealth in Nigeria, especially since the oil boom in 1970s. As this corrupt accumulation affects the public enterprises (PEs) and privatization, the process has been something 
like this: aggressively ambitious people (particularly those who lost elections or otherwise qualify for political patronage) are appointed to manage PEs. The resultant effect is that they loot the treasures of the public enterprises with impunity to establish rival private companies. It is this massive looting and incompetence that has always been the bane of the public enterprises. Paradoxically, it is these same former managers of the PEs who looted and mismanaged them and their class allies that use this contrived failure of the PEs as an excuse for their privatization. They are also the ones who will value, sell and buy these privatized public enterprises (Bogunjoko, 2000, Onimode, 2000, and Alayande, 1999).

\section{GOVERNMENT INTERVENTION}

The features of industrial relations under the current recession that affect government are mainly three. One is that, the creation of a controlled, docile and exploitable labour force for privatized industries are both the result of the initiative of private employers and of government policy. Second, the regulation of wages by the Productivity, Prices and Income Board (PP \& IB) as well as labour legislation, especially since this recession started, and third, the provisions of the economic stabilization act, have all operated in different ways to render labour docile. These are in addition to the massive retrenchment of workers since 1983. This is not to deny that there has not been excessive administrative spending in the country. But the scope, rate and terms of retrenchment have clearly intimidated the labour force into virtual paralysis, especially before the feeble air of human rights was breathed in 1986. Those issues are particularly significant since government at all levels has been and should remain a major employer of labour in the country (Afeikhene, 2000).

Adeola (2003) contends that the imposition of privatization warranted by the International Monetary Fund (IMP) conditionally has also affected employment relations since the recession. It is important to underscore the point that both privatization and the Second-tier Foreign Exchange Market (SFEM) have been imposed on the country by the IMF/World Bank coalition under the burden of the country's external debt. Even though, there were capitalist demands for privatization before the IMF negotiations, the government successfully resisted them. Meanwhile, since privatization started, the status of labour in the parastatals has been assaulted and there are genuine fears that the privatized enterprises will drastically retrench more workers in the name of rationalization, efficiency and profits. This has seriously exacerbated the current disabilities of labour and further marginalized them in industrial relations (Onimode, 1986 and Okedara, 1986).

However, the fiscal crisis of the state that has emerged from years of national economic mismanagement and the oil slump has also been operating to strain employment relations and industrial harmony. It has been used to justify stiff austerity measures that severely whittled down the gains of labour, to weaken governments' control of the excesses of the private sector in labour matters (that is, flimsy excuses for retrenchment tied to shortage of raw materials and spare parts) and thus to undermine industrial democracy in the country.

\section{THE IMPACT OF PRIVATIZATION ON INDUSTRIAL RELATIONS}

From the foregoing discussions, the impact of privatization on employment relations under recession is fairly familiar and predictable. The most serious effect is that, it has been contributing to drastic retrenchment and massive unemployment. This is the result of the allegation of over-staffing in Privatized Public Enterprises (PPEs) and the rapid penchant of the private sector for rationalization. Another way of stating this is that the objective of government in creating employment opportunities, partly by establishing PEs is not shared by the private sector. Indeed, whereas government's economic policy has an objective of reducing unemployment, the private sector does not subscribe to any such labour objective directly. This is due to the myopic profit goal of the private sector which makes it regard unemployment (and mass poverty) as functional in depressing wages, providing cheap and exploitable labour force.

Odanye (2004) posits that a related adverse consequence of the privatization of PEs is that it increases the general insecurity of the labour force. This is through the introduction of the harsh and repressive labour practices of the private sector (the privatized enterprises). Thus, the hire and fire method of personnel management in the private sector, its consequent lack of job security and social security, such as, a pension scheme, are in operation which make workers in privatized enterprises less secure, more vulnerable to exploitative abuses and, therefore, 
more marginalized in the national scheme of things.

Ayodele (2001) and Okegbenro (2002) submit that privatization is also likely to reduce the remuneration of workers, either individually or collectively. This implies that, the unemployment, resulting from privatization, often indicates a reduction in total labour earnings, even if the privatized enterprises pay higher wages, fringe benefit and social security) as the public sector did. For reasons of both unemployment and lower remuneration, privatization is likely therefore to reduce the declining share of labour in total national income.

Based on the above exposition, privatization is also likely to reduce the participation of labour, both in the management of the privatized enterprises and in the economy generally. One reason for this is the very unsatisfactory and class-biased method of privatization. As special shares have not been reserved for workers in many, if not in most, of the privatized enterprises (for instance, by investing workers' savings in the National Provident Fund and similar schemes), most of the privatized ventures have been cornered by Nigeria's tiny minority of new rich people. This method of privatization, like the similar method of indigenization during 1976/77 has the perverse effect of increasing the already gross inequality in the distribution of income and wealth between social classes and geographical regions (that is, rural/ urban) in the country. As the management of privatized enterprises involves heavy rationalization, especially in the short-run, this reduces the scope for workers' participation in managerial decisions as suggested earlier. The result will be to further marginalize workers in the ownership and control of enterprises in the economy. This is a sure process of undermining workers' rights to participated in collective bargaining (Odanye, 2004 and Akintayo, 2004).

At the international level, the foreign domination of the financial system and the economy generally must mean that privatization will tighten the foreign grip over the economy in two ways. First, it will be through the probable use of Nigerians as fronts (as was the case under indigenization) in the purchase of the public enterprises (PEs) by foreigners - that is, even if foreigners are barred from acquiring shares in the privatized enterprises directly. Second, as most financial or credit institutions are foreign-owned, the foreign owners of credit for buying privatized enterprises will unduly determine those who can acquire privatized enterprises. From the past collusion between the imperialist bourgeoisie and their local petty-bourgeois allies, the funding of privatization will thus strengthen the alliances between these two groups of exploiters and, therefore, increase the foreign grip over the economy. The overall outcome will thus be the greater control of the multinational corporations over the Nigerian economy - when the trend all over the world is to reduce their control over national economies. This situation tends to undermine the drive for national economic independence, national self-reliance and, hence, diminish the independence of labour-management relations in this Nigeria (Bogunjoko, 2000; Obadan, 2000 and Okedara, 1996).

Moreover, Omole (2003) argues that the privatization of public enterprises (PEs) is also inimical to the need for public control over the commanding heights of the economy. Even in the so-called mixed economic like Nigeria, this governmental control over the strategic industries in the economy (like finance, power, iron and steel, petroleum, and communication) is necessary for the purposeful direction of the trajectory of the economy. This is usually done through national economic planning. Therefore, the plan less anarchy of private enterprises, which privatization is encouraging will render development planning more futile because of the notorious conflict between public and private goals, between private ownership and public planning. Where this governmental control of the commanding heights of the economy and effective planning are impossible, the development of the labour force is retarded and the status of labour is threatened by the increscent crises into which the privatized and planless economy are thrown.

The alleged revenue impact of privatization is dubious at worst and marginal at best for several reasons. Omole (2003) reports that the private sector is owning many public enterprises (PEs) several millions of naira (for instance, Nigerian Breweries Plc and Guinness Nigerian Plc owed the National Electric Power Authority (NEPA) now Power Holding of Nigerian Plc (PHN) and Nigerian Telecommunication Plc. (NITEL), over a hundred million naira). The author argued further that the recovery of these debts rather than privatization would have assisted these public enterprises and eased government's financial obligations to them. In the same vein, Onimode (2001) contends that the funds for privatization were supplied largely by financial institutions owned either wholly by government; for example, Central Bank of Nigeria (CBN) or partly by government (for instance, the commercial banks). This means that, it is in effect government's funds loaned to the private sector for privatization that will be 
returned to government as the proceed from the sales of the privatized enterprises. The veracity of these claims can be verified empirically from the fact that since privatization started, the fiscal crisis of the state has not been eased. The persistence of the financial crisis of government in spite of privatization also implies the continued inability of government to provide effective leadership expected of it in labour-management relations (Onimode, 2001).

Taken collectively, these arguments imply that the overall impact of privatization of public enterprises on industrial relations in this recessional period could be extremely harsh and pernicious. The only possible marginal gains to labour are where they are offered shares in the privatized enterprises, and where some public enterprises (PSs) would have been closed down with all jobs lost in them, if they were not privatized. But these are rare exceptions to the exploitative and repressive logic of privatization with respect to industrial relations. All these imply that privatization may well provoke industrial disharmony through its harsh relative deprivation of labour.

\section{CONCLUSION}

From the viewpoint of industrial relations, there are thus several cases against the privatization of public enterprises (PEs). In the first place, the basic objectives of privatization stated in Section I of decree promulgated on privatization, can be satisfied by Commercial. This will require classifying PEs into different groups, namely, the directly productive, public utility and the service or welfare PEs (the last being scholarship, pilgrims, sports and similar boards). Then, the directly productive ones like financial, manufacturing, agricultural and similar PEs will be required to operate strictly on the basis of financial profitability by charging competitive prices. The public utilities will also be required to be commercial in operation, but where they are required to serve special areas or groups on a non-competitive basis, they should be given specific subsidy (that is, extending water to small rural communities). The service or welfare (PEs should operate on the basis of cost - effectiveness and be funded from public funds.

However, for these PEs to operate successfully on a commercial basis, the Privatization of Public Enterprises Acts should be amended accordingly to remove their shortcomings in terms of unemployment, workers` alienation and victimization that pervade the environment of privatized public enterprises in Nigeria. These include funding or capitalizing them adequately, freeing them from crippling civil service control by giving them appropriated operational autonomy, allowing them free hand to utilize the best staff available and generally removing all political interference from their functioning. But since the public interest may warrant giving specific directives to their management (for instance, extending railway services strictly non-economic routes), the financial implication of such public control should be adequately handled.

The other causes of failure of PEs due to the private sector and government policies should also be removed. These include pervasive corruption with impurity in which PEs become both extra-legal and illegal means of private accumulation of wealth without apprehension. This basic cause of public enterprises (PEs) failure has been systematically documented as a major mechanism of pirate capitalism in Nigeria. Besides those who swindle PEs must be made to refund the resources involved and be jailed without option.

Moreover, the institutional superiority of private sector over PEs, which is used for justifying privatization, is false. If public management is so inherently inefficient, why is it that top government functionaries who retire into high posts in multinational corporations immediately become so loudly successful as to be proclaimed 'wiz kids' of financial wizards? The answer lies in the sharp differences of operational autonomy and the intense exploitation permitted by government. By so doing, continuity of operational autonomy should be promoted in both public and privatized public enterprises in order to enhance increased productivity of the privatized enterprises in Nigeria.

\section{AUTHOR INFORMATION}

Akintayo, D.I. attended Oyo State College of Arts and Sciences, Ile-Ife where he obtained Higher School Certificate between 1986 - 1988. For Higher Education, he attended the University of Ibadan, Ibadan, Nigeria, between 1988-1992, 1994-1996, 1997-2001 and 2002-2004 where he obtained B.Ed English Studies with second class (Upper Division), M.Ed. Social Welfare, Ph.D Human Resource Management and Post Doctoral Masters in 
Managerial Psychology, respectively. He served as a Lecturer at Christ Apostolic Seminary, ile-Ife in Osun State of Nigeria between 1994-2001 and also worked at Olabisi Onabanjo University, Ogun State of Nigeria as Research Fellow 1 between 2002-2006 and as Senior Research Fellow between 2002-2009. In 2009, he joined the service of Osun state University in Nigeria as an Associate Professor and Head of Department in the Department of Human Resource Development, Osun State University, Okuku Campus. He has published over 50 scholarly articles in reputable local, national and International Journals and has also attended local, national and International Conferences.

\section{REFERENCES}

1. Adeola, F. (2003). The privatization process in Nigeria. Google Search.

2. Afeikhena, J. (2000). Privatization in Africa: A comparative analysis. A paper delivered at the National Centre for Economic Management and Administration, October, 1-5

3. Akintayo, M. O. (2004). Privatization and the problem of job insecurity in Nigeria. Paper presented at the Nigerian Institute of Social and Economic Research (NISER), Ibadan, Nigeria.

4. Alayande, T. (1999). Privatization of Public Utilities in Nigeria: Policy Issues for Consideration. Nigeria: Development Policy Centre, Ibadan.

5. Ayodele, A. I. (2001). Issues and cases in Public Enterprises Reforms in Nigeria: Divestitures. A paper delivered at the National Centre for Economic Management and Administration, Ibadan, Nigeria, October, $4-6$.

6. Bogunjoko, O. J. (2000). Public Enterprises Reforms: overview of Public Enterprises Reform in Nigeria. Ibadan, Nigeria: National Centre for Economic Management and Administration Publication.

7. Obadan, M. I. (2000). Privatization of Public Enterprises in Nigeria: Issues and conditions of success in the second round. Nigeria: NCEMA Monograph Series, No. 1.

8. Obadan, M. I. (2003). Privatization and commercialization of public enterprises in Nigeria. Journal of Economic Management, vol. 3(1), 9 - 78.

9. Odanye, M. O. (2004). The influence of international labour standards of promotion of markets' right in selected work organization in Lagos State, Nigeria. Unpublished Ph.D. Thesis, University of Ibadan, Ibadan.

10. Ogunde, O. (2002). The rich profit Obasanjo profitization plans and workers get power. Google Search.

11. Okedara, J. T. (1986). Industrial relation practice in privatized public organization in Nigeria. Paper presented at the National Conference on Industrial Relations Practice in Nigeria, October, 6 - 7.

12. Okegbenro, S. O. (2002). Privatization and firms' performance in Nigeria. Unpublished B.Sc. Project, University of Ibadan, Ibadan.

13. Olashore, O. (2000). Challenges of Nigeria Economic Reform in Nigeria. Ibadan: NCEMA, Publication.

14. Omole, M. A. L. (2003). Legal aspect of industrial relations in Nigeria. A paper presented at the First National Conference of Nigerian Institute of Personnel Management Oyo State Branch, University of Ibadan, $6-10$.

15. Onimode, B. (1986). The economic impact of privatization on labour-management relations in Nigeria. Paper presented at the National Workshop on Industrial Relations Practice in Nigeria, October, 1 - 12.

16. Onimode, B. (2000). Privatization of public enterprises and wastage rates in Nigeria: Issues and Policy Implications. A paper presented at national Centre for Economic Management and Administration, October, $8-12$.

17. Onimode, B. (2001). Privatization policy and business environment in Nigeria. Journal of Economic Management, vol. 3(1), $21-30$.

18. Zubairu, M. (2003). Privatization in Nigeria: The efficiency and fiscal arguments. Google Search. 
NOTES 